\title{
Standard Analytical Methods, Sensory Evaluation, NIRS and Electronic Tongue for Sensing Taste Attributes of Different Melon Varieties
}

\author{
Dzsenifer Németh ${ }^{1}$, Gábor Balázs ${ }^{1}$, Hussein G. Daood ${ }^{2}$, Zoltán Kovács ${ }^{3}{ }^{\circledR}$, Zsanett Bodor ${ }^{3}$, \\ John-Lewis Zinia Zaukuu ${ }^{3}{ }^{\mathbb{D}}$, Viktor Szentpéteri ${ }^{4}$, Zoltán Kókai ${ }^{5}$ and Noémi Kappel ${ }^{1, *(D)}$ \\ 1 Department of Vegetable and Mushroom Growing, Faculty of Horticultural Science, Szent István University, \\ Villányi út 29-43., H-1118 Budapest, Hungary; Nemeth.Dzsenifer@kertk.szie.hu (D.N.); \\ Balazs.Gabor@kertk.szie.hu (G.B.) \\ 2 Regional Knowledge Center, Szent István University, Páter Károly utca 1., H-2100 Gödöllo, Hungary; \\ Daood.Hussein@fh.szie.hu \\ 3 Department of Physics and Control, Faculty of Food Science, Szent István University, Somlói út 14-16., \\ H-1118 Budapest, Hungary; Kovacs.Zoltan3@etk.szie.hu (Z.K.); arscube@gmail.com (Z.B.); \\ zaukuu.john-lewis.zinia@hallgato.uni-szie.hu (J.-L.Z.Z.) \\ 4 Institute of Genetics, Microbiology and Biotechnology, Department of Microbiology and Environmental \\ Toxicology, Szent István University, Páter Károly út. 1., 2100 Gödöllő, Hungary; \\ Szentpeteri.Viktor@hallgato.uni-szie.hu \\ 5 Department of Postharvest Science and Sensory Evaluation, Faculty of Food Science, Szent István University, \\ Villányi út 35-43., H-1118 Budapest, Hungary; Kokai.Zoltan@etk.szie.hu \\ * Correspondence: Kappel.Noemi@kertk.szie.hu; Tel.: +36-30-215-8922
}

Received: 15 October 2019; Accepted: 13 November 2019; Published: 16 November 2019

\begin{abstract}
Grafting by vegetables is a practice with many benefits, but also with some unknown influences on the chemical composition of the fruits. Our goal was to assess the effects of grafting and storage on the extracted juice of four orange-fleshed Cantaloupe type (Celestial, Donatello, Centro, Jannet) melons and two green-fleshed Galia types (Aikido, London), using sensory profile analysis and analytical instruments: An electronic tongue (E-tongue) and near-infrared spectroscopy (NIRS). Both instruments are known for rapid qualitative and quantitative food analysis. Linear discriminant analysis (LDA) was used to classify melons according to their varieties and storage conditions. Partial least square regression (PLSR) was used to predict sensory and standard analytical parameters. Celestial variety had the highest intensity for sensory attributes in Cantaloupe variety. Both green and orange-fleshed melons were discriminated and predicted in LDA with high accuracies $(100 \%)$ using the E-tongue and NIRS. Galia and Cantaloupe inter-varietal classification with the E-tongue was $89.9 \%$ and $82.33 \%$, respectively. NIRS inter-varietal classification was $100 \%$ with Celestial variety being the most discriminated as with the sensory results. Both instruments, classified different storage conditions of melons (grafted and self-rooted) with high accuracies. PLSR showed high accuracy for some standard analytical parameters, where significant differences were found comparing different varieties in ANOVA.
\end{abstract}

Keywords: melon varieties; sensory evaluation; NIRS; electronic tongue; refraction; vitamin C content; carotenoid content

\section{Introduction}

Melon is grown on 3.5-3.7 million hectares around the world. Nowadays, a strong increase in production volumes and consumption can be observed in developing countries with high 
populations [1]. Grafting of vegetable plants is already common practice in the word. The main argument for melon grafting is the gained increase in tolerance against pests [2], and abiotic stresses [3] and the increase in yield [4]. Several research groups also agreed that the physical characteristics of the Solanaceae and Cucurbitaceae families were not affected by grafting [3]. Fruit quality of melon is made up of several factors, like the visual appearance, texture, and the taste and aroma, which are the most important characteristics for consumers [5]. There are studies showing that grafting can influence the soluble sugar content of melon in a negative way. At the late 1940s [6] it was recorded that the Cucurbita moschata rootstock causes weaker texture and aroma in the grafted Honey Dew' fruits, although it also established tolerance against fusarium wilt. Grafting did reduce sugar content by 1 Brix $^{\circ}$ in case of watermelon and melon as well in the experiments of international studies [7-9]. Compared to 350 melon varieties and found that the vitamin C content of them is between $0.75-35.3 \mathrm{mg} / 100 \mathrm{~g}$. According to Bíró and Lindner (1988), orange-fleshed melons contain $35 \mathrm{mg} / 100 \mathrm{~g}$ vitamin C, whereas, green-fleshed melons only contain $25 \mathrm{mg} / 100 \mathrm{~g}$ vitamin C [10]. Condurso et al. (2012) concluded that the carotenoid content of the 'Proteo' melon variety (Cucumis melo var. reticulatus) increased when grafted on hybrid pumpkin rootstock [11]. The experiment of Zhou et al. (2014) revealed that plants grafted to 'Elis', 'P360', 'RS841' and 'AS10' rootstocks lutein content is significantly higher, $\beta$-carotene level increases eight fold and $\alpha$-carotene level increases by $56 \%$ when compared to control plants grafted on 'P360' [12]. In the study of Zhou et al. (2014) the combination of 'Lyu'-'Nanzhen No. 1' plants resulted in four times higher fruit $\beta$-carotene content compared to fruits grown on nongrafted plants [12]. However, not all grafting combination is favorable on carotenoid content, which was shown in the study of Verzera et al. (2014) where the use of 'Energy' and 'Sting' rootstocks resulted in $55 \%$ decrease in $\beta$-carotene content compared to control [13]. Storage of vegetables and fruits is necessary to lengthen the consumption and processing season of them. To avoid over-ripening, it is advised to store melon at low temperature, but since it is a cold-sensitive fruit, after harvest, a gradual approach has to be followed during the cooling process until the reach of $6-10{ }^{\circ} \mathrm{C}$ which has the desired preservative effect. At 0 Celsius degree freeze damage is caused to the fruit, due to this, it becomes vitrificated, and whole units become spoilt that way [14]. The data suggest that the effects of rootstocks on flesh firmness varied depending on the rootstock and the scion [15].

Sensory properties of fruits are very important factors in consumer acceptance; therefore, objective tests for determining the preferred sensory attributes is essential. Sensory test based on ISO standards can be performed by panels for the description of different fruits, such as melon [16,17]. Electronic sensory instruments like electronic tongues and electronic noses are also available and used in food science. Electronic tongues are designed to work like human tongues, but with a higher sensitivity to flavors and aromas working like a fingerprint method. Electronic tongues were applied in several fields of food studies, for instance, classification of different varieties of fruits and vegetables, testing the authenticity of foods and beverages $[18,19]$ or predicting sweetness and sugar content [20]. Hungarian researchers could discriminate regions of watermelon samples based on the results of the electronic tongue [21]. The electronic tongue was also used for discriminate between different processes [22] or storage conditions [18].

Also, in the scope of advanced analytical instruments for melon quality, is the near-infrared spectroscopy (NIRS). NIRS is a well-established technique that operates within a wavelength range of 700-2500 nm [23]. The NIRS principle basically encompasses the emission, absorption and reflection of light which, are dependent on the chemical composition of the product (microstructure) and its light-scattering properties. Advanced multivariate statistical techniques, such as least discriminant analysis and partial least squares regression, are then applied to extract the required information from the usually convoluted spectra [24]. Advantages of NIRS include: Waste-free rapid analysis, low cost per evaluation, and simultaneously testing for diverse properties from a single spectrum. NIRS has been used to predict the pulp color difference of melon [25] and also the sugariness and hardness of different melon varieties [26]. The principles and advantages of NIRS makes it suitable for breeding, research that often involves genotypic or phenotypic discrimination, but there is a paucity of a report 
about its application in this context. Considering that melons are a very important and popular fruit substitute vegetable, little scientific results have been published so far on the correlation between instrumental and organoleptic properties of melon, particularly, the influence of technology effects, such as storage or grafting.

The aim of our study was to determine the compositional differences between five melon varieties grafted and stored under different conditions $\left(2{ }^{\circ} \mathrm{C}\right.$ and $\left.17^{\circ} \mathrm{C}\right)$ and to classify the predict their compositional qualities using advanced methods (e-tongue and NIRS).

\section{Materials and Methods}

Examinations were performed from late summer to autumn in 2018. Experimental samples were gathered from several farmers. Altogether six melon varieties were examined, four orange-fleshed Cantaloupe type (Celestial, Donatello, Centro, Jannet) and two green-fleshed Galia type (Aikido, London). Two experiments were carried out, the first aimed towards comparing varieties and the second was to examine the effects of different storage conditions. Variety comparison was performed with Celestial, Donatello, Centro, Aikido and London varieties. Five different plants of each variety were harvested and later on used in the experiments (variety dataset) resulting in a total of 25 samples ( 5 varieties and five repeats each). In case of the Jannet variety (Cantaloupe type) we had fruits originating from grafted and self-rooted plants as well. Five different plants of each variety wereharvested and used for the storage experiments (storage dataset). The samples included fruits processed freshly and stored for 7 days at $2{ }^{\circ} \mathrm{C}$ and $17^{\circ} \mathrm{C}$ were compared.

\subsection{Standard Analytical Methods}

The use of standard analytical methods was necessary to support the data obtained by NIRS and electronic tongue measurements. The water-soluble solids content was measured with a digital hand refractometer (PAL-1, ATAGO). After preparation of the samples, a few drops of fruit juice were dropped onto the surface of the prism, and the instrument read the measurement results. The machine was then calibrated with distilled water. Brix ${ }^{\circ}$ corresponds to the sugar percentage in the solution, i.e., $1 \%$ is equal to $1 \mathrm{~g}$ sugar per $100 \mathrm{~g}$ solution. To determine the carotenoid profile and the vitamin C content, we used the Hitachi Chromaster HPLC. The isolation and data processing were operated by EZChrom Elite software. To measure the vitamin content, samples have been injected on a reverse-phase C18 Nautilus, $150 \times 4.6 \mathrm{~mm}$ (Macherey-Nagel, Düren, Germany) column. To determine the exact amount, a known amount of standard material (Sigma Aldrich, Budapest) was injected, and the concentration values for the peaks obtained were calculated. The maximum absorption of vitamin $C$ was detected at $244 \mathrm{~nm}$. To measure the carotenoids, after draining solvents were removed by vacuum distillation (RVO 400, Vacuubrand, Germany) at $40^{\circ} \mathrm{C}$. Samples have been filtrated through a $0.45 \mu \mathrm{m}$ diameter PTFE HPLC filter, before injection on the column. Carotenoids were separated on a Purospher ${ }^{\circledR}$ STAR RP C18 end-capped $3 \mu \mathrm{m}, 250 \times 4.6 \mathrm{~mm}$ column with $50 \mathrm{~min}$ long gradient elution according to the method of Daood et al. (2014) [27]. Peaks were identified by comparing their retention time and maximum absorbance to standards (Sigma Aldrich, Budapest). The carotenoids were detected between 195 and $700 \mathrm{~nm}$.

\subsection{Sensory Tests}

Samples were prepared 30 min before tasting. First, the sensory attributes and their corresponding reference values were determined, in order to reduce the variation in the resulting dataset. Then, sensory tests were performed according to ISO 13299 standard by 10 panelists who evaluated the followings: The presence of fermented aroma (since it was a storage test), sweet aroma, flesh color, texture, juiciness, sweet taste, fermented flavor, after taste, and taste persistence [28]. The combined results of the properties were plotted on profile diagrams, which were prepared by ProfiSens, a sensory analysis software. Tests were performed according to ISO 8589, and differences between data were evaluated with univariate ANOVA and Fisher LSD significance level evaluation procedures [29]. 


\subsection{Electronic Tongue Measurements}

Electronic tongue measurements were carried out with Alpha Astree [30] potentiometric electronic tongue, containing seven sensors (ISFET-BB, CA, HA, JB, JE, GA, ZZ), that have been developed for liquid food applications. Five tubes of each melon sample were frozen, then melted up and filtered. For electronic tongue measurements, 10 times dilution $(10 \mathrm{~mL}$ of filled up to volume in $100 \mathrm{~mL}$ volumetric flask) was prepared from each sample in three replicates resulting in 15 replicate sample per type and storage level. Melons for variety and storage discrimination was measured on two following days (first day for variety test, and the second day for storage test). Each day three sequences were formed, containing two replicates for each sample. Five replicate samples were obtained from five individual plants for each group of the variety and storage data sets, respectively. Each sample was measured four times with the electronic tongue resulting in 100 readings for each variety and storage data set. The last $10 \mathrm{~s}$ of the sensor signals of each sample, were averaged and exported into an excel sheet for statistical analysis Figure 1.

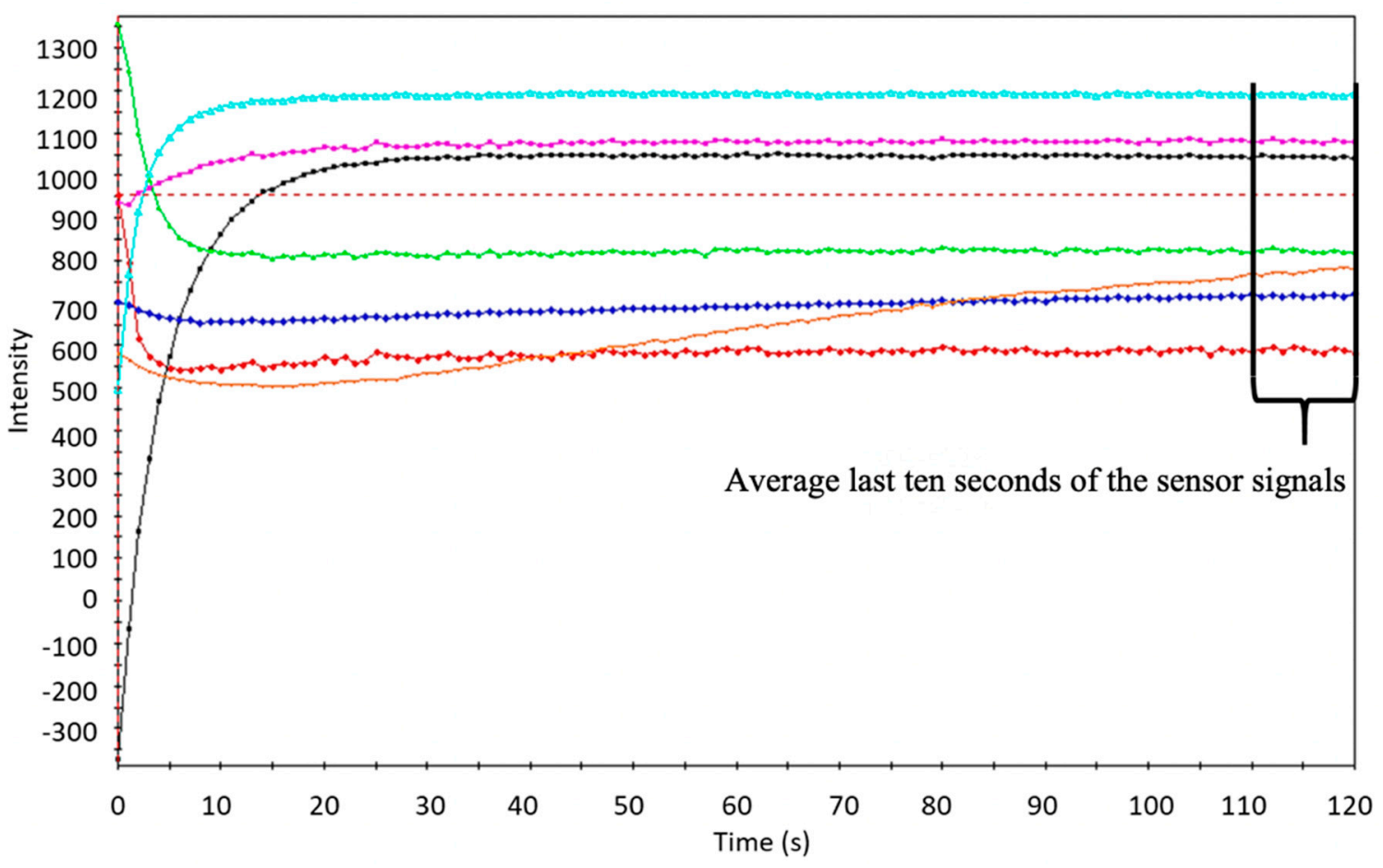

Figure 1. Electronic tongue sensor signals acquired in the $120 \mathrm{~s}$ of signal acquisition of one selected Celestial melon sample.

\subsection{Near-Infrared Spectroscopy (NIRS) Measurements}

Metri analyzer (benchtop spectrometer) was used for spectra collection. Transflectance spectra were collected using a cuvette providing $0.4 \mathrm{~mm}$ layer thickness of the tested melon varieties. The samples were prepared the same way as for electronic tongue measurement, but there was no dilution applied. Three consecutive scans of all the five repeats were collected, while using purified water (MQ) as a control in a spectral step of $3 \mathrm{~nm}$. The spectral acquisition was performed at room temperature. In total, 75 spectra of melon samples were recorded for each variety dataset and storage dataset. Data analysis was done at the spectral range of 950-1650 nm after raw spectra assessment. Spectra pretreated was done first with detrended and Savitzky-Golay smoothing filter using second order polynomial in R-studio using the "aquap2" package [31]. 


\subsection{Statistical Evaluation}

Statistical evaluation of the results of standard analytical methods properties, such as Brix ${ }^{\circ}$, vitamin $C$ and carotenoid profile was performed with descriptive statistics (mean and standard deviation) and ANOVA test followed by Tukey-HSD pair wised comparison between varieties and between storage types for each parameter at $p<0.05$ significance level. Results of the electronic tongue were evaluated after drift correction of the raw results to exclude the effect of the ageing of the organic membranes, and these drift corrected results were used for the representation of the results of the ET. Results of ET and NIRS were evaluated with chemometric methods: Principal component analysis (PCA), linear discriminant analysis (LDA) and partial least square regression (PLSR). PCA was used as an exploratory analysis for identification of the outliers and describing the main patterns of the variety and storage data set. LDA was used for building classification models for different varieties and a separate model for storage conditions. Models were validated with threefold cross validation. Partial least square regression was carried out to predict the results of standard analytical methods and sensory test with leave one out cross validation. Root mean square error was also calculated for the training (RMSEC) and validation (RMSECV) data sets separately for the data set of varieties and storage measurements. Microsoft Excel, SPSS 25 and R-project 3.5.2 software were used for the data evaluation.

\section{Results}

\subsection{Results of the Standard Analytical Measurment}

\subsubsection{Results of the Variety Data Set}

Results of standard analytical methods can be seen in Table 1. Results of ANOVA test showed a significant difference in each parameter between Cantaloupe and Galia type melons. In Galia type melons significant difference was found in violaxanthin and chlorophyll components between Aikido and London varieties. Results of Cantaloupe type melons showed a significant difference in $\beta$-carotene between Celestial, Centro and Donatello. Moreover, a significant difference was obtained in violaxanthin between Centro and Donatello, and in total carotene Centro also distinguished from the two other types and in vitamin $C$ from Celestial variety.

Table 1. Results of the standard analytical methods of the different varieties (values are in $\mu \mathrm{g} / \mathrm{mL}$ ).

\begin{tabular}{|c|c|c|c|c|c|}
\hline & \multicolumn{2}{|c|}{ Galia Type } & \multicolumn{3}{|c|}{ Cantaloupe Type } \\
\hline & Aikido & London & Celestial & Centro & Donatello \\
\hline Phytoene & - & - & $3.545 \pm 0.76^{\mathrm{a}}$ & $2.919 \pm 0.828^{\mathrm{a}}$ & $2.367 \pm 0.222^{\mathrm{a}}$ \\
\hline Phyto floene & - & - & $3.214 \pm 0.731^{\mathrm{a}}$ & $2.922 \pm 0.758^{\mathrm{a}}$ & $1.95 \pm 0.314^{\mathrm{a}}$ \\
\hline Cis $\beta$-carotene & $0.011 \pm 0^{\mathrm{a}}$ & $0.085 \pm 0.021^{\mathrm{a}}$ & $0.539 \pm 0.17^{b}$ & $0.76 \pm 0.225^{\mathrm{b}}$ & $0.441 \pm 0.037^{b}$ \\
\hline$\beta$-carotene & $0.601 \pm 0.056^{\mathrm{a}}$ & $3.606 \pm 0.385^{\mathrm{a}}$ & $48.074 \pm 11.033^{\mathrm{b}}$ & $66.056 \pm 8.28^{c}$ & $31.895 \pm 3.063^{b}$ \\
\hline$\zeta$-carotene & $0.018 \pm 0.004^{\mathrm{a}}$ & $0.085 \pm 0.021^{\mathrm{a}}$ & $3.079 \pm 0.747^{c}$ & $2.674 \pm 0.521^{b, c}$ & $1.791 \pm 0.313^{b}$ \\
\hline Mutatoxantin & - & - & $0.085 \pm 0.021^{\mathrm{a}}$ & $0.245 \pm 0.139^{a}$ & $0.085 \pm 0.021^{\mathrm{a}}$ \\
\hline Lutein & $0.822 \pm 0.076^{\mathrm{b}}$ & $0.871 \pm 0.203^{b}$ & $0.417 \pm 0.042^{\mathrm{a}}$ & $0.502 \pm 0.076^{\mathrm{a}}$ & $0.282 \pm 0.021^{\mathrm{a}}$ \\
\hline Violaxantin & $0.809 \pm 0.037^{d}$ & $0.615 \pm 0.053^{c}$ & $0.3 \pm 0.028^{a, b}$ & $0.373 \pm 0.092^{b}$ & $0.187 \pm 0.031^{\mathrm{a}}$ \\
\hline Total carotene & $5.275 \pm 1.658^{a}$ & $7.973 \pm 1.888^{a}$ & $53.361 \pm 11.408^{\mathrm{b}}$ & $72.68 \pm 8.28^{c}$ & $35.944 \pm 4.598^{b}$ \\
\hline Chlorophyll A & $2.122 \pm 0.309^{a}$ & $1.705 \pm 0.085^{a}$ & - & - & - \\
\hline Chlorophyll B & $0.809 \pm 0.133^{\mathrm{b}}$ & $0.232 \pm 0.021^{\mathrm{a}}$ & - & - & - \\
\hline Vitamin C & - & $0.15 \pm 0.26^{\mathrm{a}}$ & $34.917 \pm 2.15^{c}$ & $26.317 \pm 5.212^{\mathrm{b}}$ & $30.74 \pm 0.52^{b, c}$ \\
\hline Brix $^{\circ}$ & $8.978 \pm 1.357^{\mathrm{a}}$ & $8.367 \pm 0.633^{\mathrm{a}}$ & $7.744 \pm 0.707^{\mathrm{a}}$ & $8.367 \pm 3.221^{\mathrm{a}}$ & $7.622 \pm 0.662^{\mathrm{a}}$ \\
\hline
\end{tabular}

Mean \pm Standard deviation, letters $(\mathrm{a}, \mathrm{b}, \mathrm{c}, \mathrm{d})$ are showing the significant differences between varieties per each parameter resulted by ANOVA test followed by Tukey-HSD post hoc test at $p<0.05$. 


\subsubsection{Results of Storage Data Set}

ANOVA results showed a significantly higher carotenoid content and Brix ${ }^{\circ}$ values for self-rooted fresh melons (Table 2). Grafted fresh melon had also higher $\beta$-carotene, mutatoxanthin, lutein and total carotene content than the stored group of melons. Highest vitamin $C$ content was obtained for grafted melons stored at $2{ }^{\circ} \mathrm{C}$, with significantly higher values than the other groups. However, self-rooted melons stored at $2{ }^{\circ} \mathrm{C}$ showed also significantly higher vitamin $\mathrm{C}$ content than the ones stored at $17^{\circ} \mathrm{C}$. Grafted melons showed significantly lower Brix ${ }^{\circ}$ compared to self-rooted melons.

Table 2. Results of standard analytical methods for the storage test set (values are in $\mu \mathrm{g} / \mathrm{mL}$ ).

\begin{tabular}{|c|c|c|c|c|c|}
\hline & Grafted Fresh & Grafted $2{ }^{\circ} \mathrm{C}$ & Self-Rooted Fresh & Self-Rooted $2^{\circ} \mathrm{C}$ & Self-Rooted $17^{\circ} \mathrm{C}$ \\
\hline Phytoene & $1.68 \pm 0.62^{\mathrm{a}}$ & $1.13 \pm 0.33^{\mathrm{a}}$ & $2.98 \pm 0.63^{b}$ & $1.66 \pm 0.33^{\mathrm{a}}$ & $1.79 \pm 0.4^{\mathrm{a}, \mathrm{b}}$ \\
\hline Phytofluene & $2.09 \pm 0.87^{\mathrm{a}, \mathrm{b}}$ & $0.95 \pm 0.18^{\mathrm{a}}$ & $3.56 \pm 0.85^{b}$ & $1.46 \pm 0.49^{\mathrm{a}}$ & $1.73 \pm 0.23^{\mathrm{a}}$ \\
\hline Cis $\beta$-Carotene & $3.8 \pm 2.22^{\mathrm{a}}$ & $1.07 \pm 0.64^{\mathrm{a}}$ & $10.43 \pm 2.76^{\mathrm{b}}$ & $1.05 \pm 0.35^{\mathrm{a}}$ & $1.25 \pm 0.41^{\mathrm{a}}$ \\
\hline$\beta$-Carotene & $71.39 \pm 18.77^{b}$ & $30.91 \pm 3.68^{\mathrm{a}}$ & $116.41 \pm 16.74^{\mathrm{c}}$ & $48.21 \pm 13.98^{\mathrm{a}, \mathrm{b}}$ & $54.49 \pm 9.6^{\mathrm{a}, \mathrm{b}}$ \\
\hline$\zeta$-Carotene & $3.32 \pm 0.54^{\mathrm{a}}$ & $1.5 \pm 0.17^{\mathrm{a}}$ & $7.48 \pm 2.22^{b}$ & $2.63 \pm 0.81^{\mathrm{a}}$ & $3.41 \pm 0.63^{\mathrm{a}}$ \\
\hline Mutatoxanthin & $0.28 \pm 0.09^{b}$ & $0.13 \pm 0.08^{a, b}$ & $0.23 \pm 0.08^{a, b}$ & $0.06 \pm 0.01^{\mathrm{a}}$ & $0.13 \pm 0.02^{\mathrm{a}, \mathrm{b}}$ \\
\hline Lutein & $0.5 \pm 0.09^{\mathrm{b}}$ & $0.24 \pm 0.02^{\mathrm{a}}$ & $0.54 \pm 0.11^{b}$ & $0.38 \pm 0.13^{\mathrm{a}, \mathrm{b}}$ & $0.24 \pm 0.04^{\mathrm{a}}$ \\
\hline Violaxanthin & $0.07 \pm 0.04^{\mathrm{a}}$ & $0.17 \pm 0.02^{\mathrm{a}, \mathrm{b}}$ & $0.28 \pm 0.15^{\mathrm{a}, \mathrm{b}}$ & $0.32 \pm 0.08^{b}$ & $0.27 \pm 0.06^{\mathrm{a}, \mathrm{b}}$ \\
\hline Total carotene & $81.14 \pm 20.06^{\mathrm{b}}$ & $35.64 \pm 2.89^{\mathrm{a}}$ & $129.72 \pm 12.7^{c}$ & $54.14 \pm 13.19^{\mathrm{a}, \mathrm{b}}$ & $61.27 \pm 8.28^{\mathrm{a}, \mathrm{b}}$ \\
\hline Brix $^{\circ}$ & $5.67 \pm 0.32^{\mathrm{b}}$ & $4.41 \pm 0.32^{\mathrm{a}}$ & $8.57 \pm 1^{\mathrm{d}}$ & $7.56 \pm 1.16^{\mathrm{c}, \mathrm{d}}$ & $7.21 \pm 0.63^{c}$ \\
\hline Vitamin C & - & $132.29 \pm 27.78^{c}$ & - & $5.49 \pm 2.16^{\mathrm{b}}$ & $1.93 \pm 0.84^{\mathrm{a}}$ \\
\hline
\end{tabular}

Mean \pm Standard deviation, letters are showing the significant differences between varieties per each parameter resulted by ANOVA test followed by Tukey-HSD post hoc test at $p<0.05$.

\subsection{Results of the Classical Sensory Test}

Results of variety data, (Figure 2a,b) set for the Cantaloupe type melons showed significant differences in four parameters, based on the results of ANOVA and pair wised comparison at $p<0.05$ significance level. Celestial showed significantly higher fermented aroma compared to Centro, however, significantly higher fermented taste compared to the other two groups. Texture value of Donatello was significantly higher compared to Centro and Celestial, while Centro showed significantly lower juiciness compared to the two other variety. Comparing the Galia type melons significant difference can be observed in three parameters: Aikido had significantly intense fermented taste, aroma and flesh color compared to London.

In the case of the storage data set (Figure 2c,d) for fresh melons, significant differences between grafted and self-rooted melon were obtained for eight parameters. Fermented taste and aroma did not show a significant difference between the two before mentioned types, while with the exception of juiciness self-rooted melon showed significantly higher values compared to grafted melon. Melons stored at $2{ }^{\circ} \mathrm{C}$ showed similar results, apart from in this case there were no significant difference in flesh color and fermented flavor, while comparing the fresh ones, here grafted melon showed significantly more intense fermented aroma comparing the self-rooted melon. 

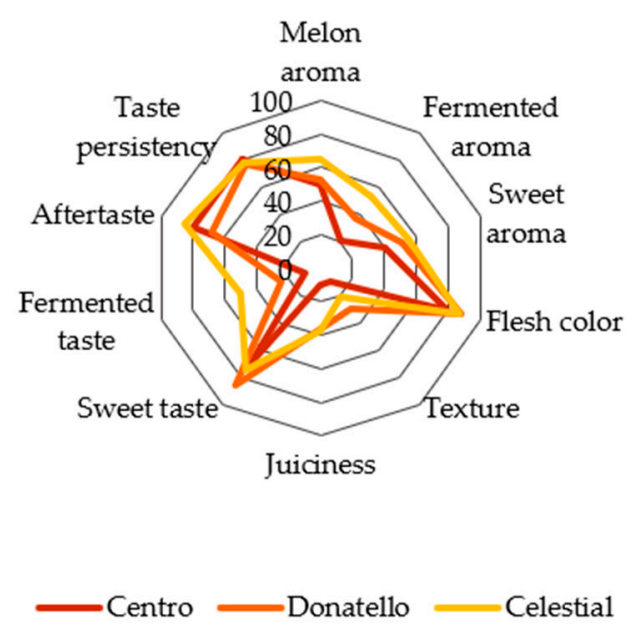

(a)

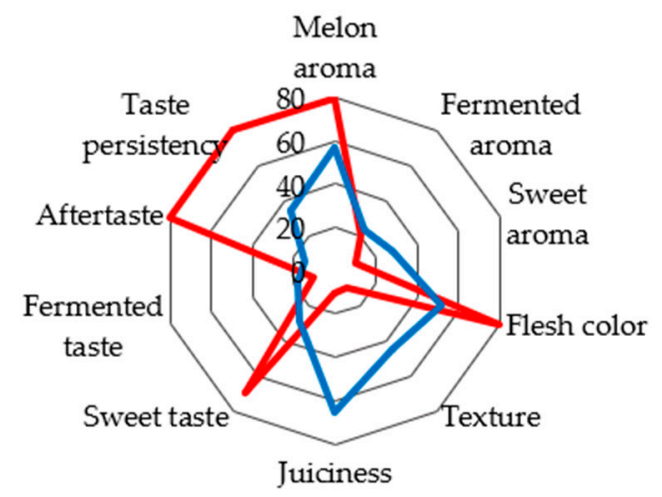

- Self-rooted fresh Grafted Fresh

(c)
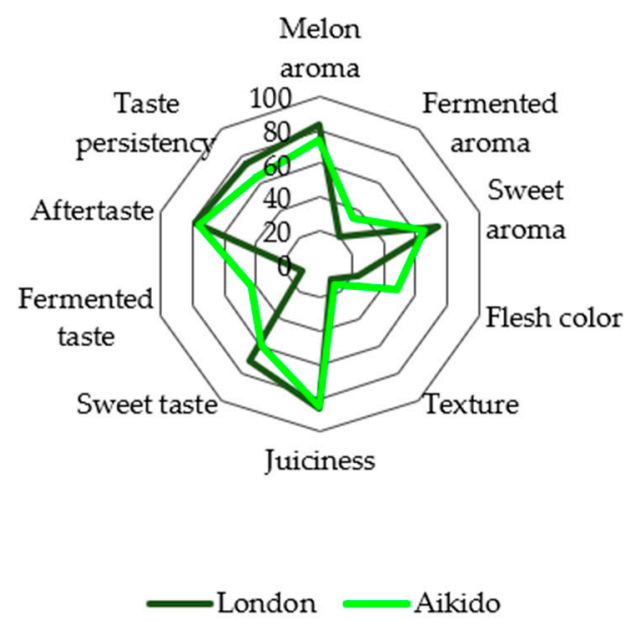

(b)

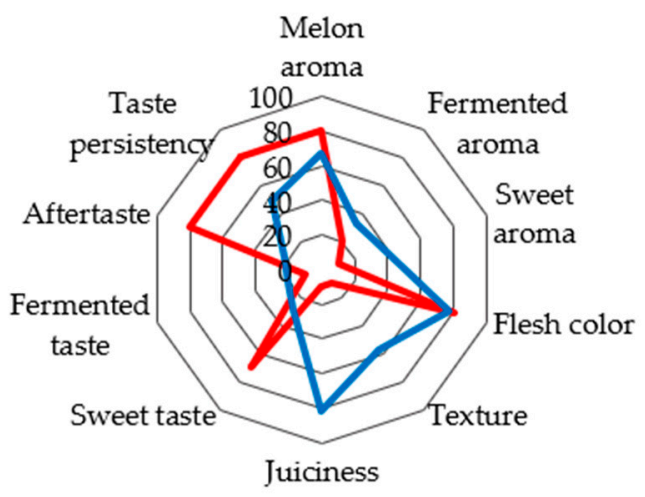

Self-rooted $2^{\circ} \mathrm{C} \longrightarrow$ Grafted $2^{\circ} \mathrm{C}$

(d)

Figure 2. Results of the sensory profile test: $(\mathbf{a}, \mathbf{b})$ Results of the variety data set $n=11$, (c,d) results of the storage data set $n=10$.

\subsection{Results of Classification Models for Electronic Tongue and NIRS Measurements}

\subsubsection{Results of the Variety Test Set}

PCA results of the electronic tongue showed a separation tendency mainly between Cantaloupe and Galia type melons based on PC1. LDA classification results showed similar results and trends (Figure 3). Detailed results of the classification model can be found in Table 3. LDA model built for the classification of the five varieties presented average recognition and prediction abilities of $85.51 \%$ and $59.01 \%$, respectively, for the electronic tongue. Centro was classified correctly during training, while in validation misclassification was found belonging to Donatello type in $4.95 \%$. Aikido and London varieties completely were distinguished from Celestial, Donatello and Centro types. This tendency can be seen on Figure 3. and have been proven by the model built for discriminating the yellow (Cantaloupe type) and green fleshed (Galia type) melons, where $100 \%$ correct classification was obtained both for recognition and prediction. 
Table 3. Linear discriminant analysis (LDA) classification results of the variety data set based on the results of electronic tongue (ET) and near-infrared spectroscopy (NIRS).

\begin{tabular}{|c|c|c|c|c|c|c|c|c|c|c|c|c|c|c|}
\hline \multirow[b]{2}{*}{ Color } & \multirow[b]{2}{*}{ Total Accuracy } & \multicolumn{6}{|c|}{ Electronic Tongue } & \multirow[b]{2}{*}{$\begin{array}{c}\text { Total } \\
\text { Accuracy }\end{array}$} & \multicolumn{6}{|c|}{ NIRS } \\
\hline & & Varieties & Celestial & Centro & Donatello & Aikido & London & & Varieties & Celestial & Centro & Donatello & Aikido & London \\
\hline Yellow & \multirow{5}{*}{$\begin{array}{l}\text { Recognition } \\
\quad 85.51 \%\end{array}$} & Celestial & 72.49 & 0 & 24.98 & 0 & 0 & \multirow{5}{*}{$\begin{array}{l}\text { Recognition } \\
100 \%\end{array}$} & Celestial & 100 & 0 & 0 & 0 & 0 \\
\hline Yellow & & Centro & 0 & 100 & 0 & 0 & 0 & & Centro & 0 & 100 & 0 & 0 & 0 \\
\hline Yellow & & Donatello & 27.51 & 0 & 75.02 & 0 & 0 & & Donatello & 0 & 0 & 100 & 0 & 0 \\
\hline Green & & Aikido & 0 & 0 & 0 & 90.02 & 9.98 & & Aikido & 0 & 0 & 0 & 100 & 0 \\
\hline Green & & London & 0 & 0 & 0 & 9.98 & 90.02 & & London & 0 & 0 & 0 & 0 & 100 \\
\hline Yellow & \multirow{5}{*}{$\begin{array}{c}\text { Cross validated } \\
59.03 \%\end{array}$} & Celestial & 25.04 & 0 & 74.96 & 0 & 0 & \multirow{5}{*}{$\begin{array}{l}\text { Cross } \\
\text { Validated } \\
54.75 \%\end{array}$} & Celestial & 80.16 & 0 & 0 & 6.6 & 6.61 \\
\hline Yellow & & Centro & 0 & 95.05 & 0 & 0 & 0 & & Centro & 0 & 46.69 & 0 & 20 & 6.61 \\
\hline Yellow & & Donatello & 74.96 & 4.95 & 25.04 & 0 & 0 & & Donatello & 6.61 & 20.04 & 73.4 & 40 & 6.61 \\
\hline Green & & Aikido & 0 & 0 & 0 & 80.03 & 29.99 & & Aikido & 6.61 & 6.61 & 26.6 & 20 & 26.65 \\
\hline Green & & London & 0 & 0 & 0 & 19.97 & 70.01 & & London & 6.61 & 26.65 & 0 & 13.4 & 53.51 \\
\hline
\end{tabular}




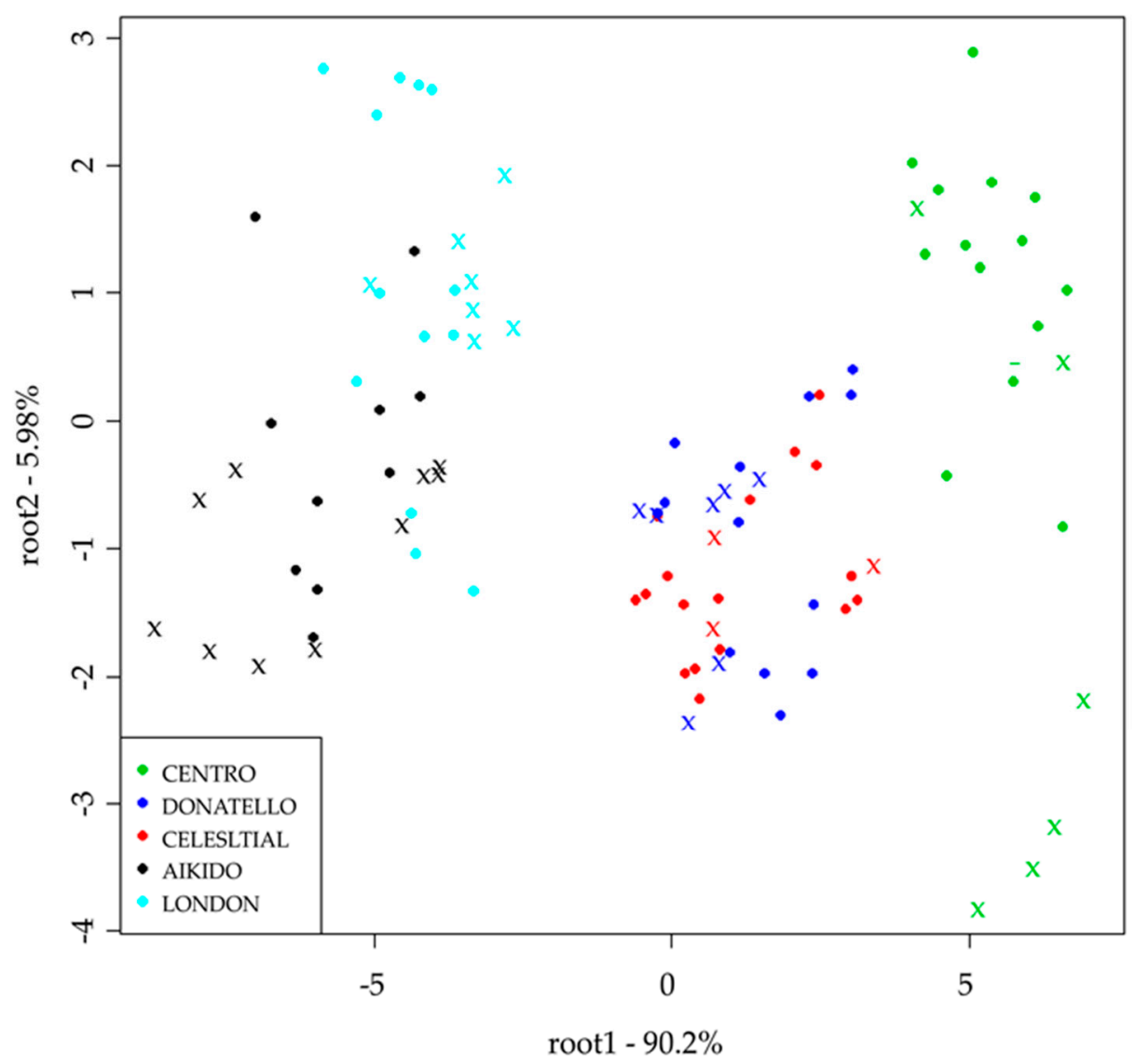

Figure 3. LDA classification results of the electronic tongue for differentiation of the five varieties after drift correction and outlier detection $(n=100)$ otraining $\times$ validation.

Classification of $100 \%$ was obtained for recognition with the NIRS, but with a prediction accuracy of $54.75 \%$ for the classification of the five tested variates. Celestial and Donatello varieties were the most accurately predicted with an accuracy of $80.16 \%$ and $73.4 \%$, respectively. During cross validation Aikido had the lowest prediction accuracy of $20 \%$, and misclassification of $40 \%, 20 \%, 13.4 \%$ and $6.6 \%$ as Donatello, Centro, London and Celestial varieties, respectively. Donatello, Aikido and London varieties were in certain cases $(6.1 \%)$ misclassified as Celestial variety Classification tables were also, independently built for the Galia (Table 4) and Cantaloupe (Table 5) types with the electronic tongue and NIRS.

Table 4. LDA classification results of Galia type melons based on the results of ET and NIR.

\begin{tabular}{cccccccc}
\hline \multicolumn{3}{c}{ Electronic Tongue } & \multicolumn{4}{c}{ NIRS } \\
\hline Total Accuracy & Varieties & Aikido & London & Total Accuracy & Varieties & Aikido & London \\
\hline Recognition & Aikido & 92.5 & 12.52 & \multirow{2}{*}{ Recognition 100\% } & Aikido & 100 & 0 \\
$89.99 \%$ & London & 7.5 & 87.48 & & London & 0 & 100 \\
\hline Cross Validated & Aikido & 89.96 & 14.99 & Cross Validated & Aikido & 100 & 20 \\
$87.49 \%$ & London & 10.04 & 85.01 & $90 \%$ & London & 0 & 80 \\
\hline
\end{tabular}


LDA classification model built for Galia type melons provided average recognition and prediction abilities of $89.99 \%$ and $87.49 \%$, respectively, for the electronic tongue. Recognition was $100 \%$ with $90 \%$ prediction for all Galia varieties using the NIRS. London variety- $14.99 \%$ and $20 \%$ were misclassified as Aikido variety with the electronic tongue and NIRS, respectively (Table 4).

Cantaloupe type melons model resulted in average recognition and prediction abilities of $82.33 \%$ and $51.19 \%$ using data from the electronic tongue. Centro was classified correctly, while Celestial and Donatello types showed misclassifications belonging to each other. There was $100 \%$ recognition for all varieties and $64.47 \%$ average prediction with the NIRS. Celestial variety had the highest prediction accuracy of $93.4 \%$ with $6.6 \%$ being misclassified as Donatello. Donatello variety had the lowest prediction accuracy, with $40 \%$ being, misclassified as Centro (Table 5).

Table 5. LDA classification results of Cantaloupe type melons based on results of ET and NIR.

\begin{tabular}{|c|c|c|c|c|c|c|c|c|c|}
\hline Total Accuracy & \multicolumn{4}{|c|}{ Electronic Tongue } & \multicolumn{5}{|c|}{ NIRS } \\
\hline \multirow{2}{*}{$\begin{array}{c}\text { Recognition } \\
82.33 \%\end{array}$} & Celestial & 77.75 & 0 & 30.77 & \multirow{2}{*}{$\begin{array}{c}\text { Recognition } \\
100 \%\end{array}$} & Celestial & 100 & 0 & 0 \\
\hline & Donatello & 22.25 & 0 & 69.23 & & Donatello & 0 & 0 & 100 \\
\hline $\begin{array}{c}\text { Cross Validated } \\
51.19 \%\end{array}$ & Celestial & 25 & 0 & 71.43 & $\begin{array}{c}\text { Cross Validated } \\
64.47 \%\end{array}$ & Celestial & 93.4 & 0 & 26.6 \\
\hline
\end{tabular}

\subsubsection{Results of Storage Test Set}

Results of PCA model for the storage test set showed the separation of the grafted and self-rooted melons through PC1, which describes the $99.01 \%$ of the total variance. Through PC2, the separation tendency of the different storage conditions was observed. LDA model built for the classification of five storage levels provided average recognition and prediction abilities of $92.01 \%$ and $87.03 \%$, respectively. Self-rooted fresh and at $2{ }^{\circ} \mathrm{C}$ stored melons were classified correctly during training, in validation the classification accuracy was $93.4 \%$. Grafted fresh melons showed classification accuracy for training in $86.7 \%$, for validation $80 \%$, misclassification was found belonging to grafted, stored at $2{ }^{\circ} \mathrm{C}$. The detailed result of the model can be found in Table 6. The tendency of the separations of the LDA results can be seen in Figure 4. Root 1 (73.59\%) mainly shows the separation between grafted and self-rooted types, while root 2 (19.33\%) shows the separation between groups of fresh and stored melons.

NIRS results for storage showed 100\% classification for the different storage conditions of both grafted and self-root melons. For validation, melons stored at $2{ }^{\circ} \mathrm{C}$ had the highest accuracy irrespective of whether they were grafted or self-rooted. Self-rooted melons stored at $17^{\circ} \mathrm{C}$ also showed a high validation accuracy. 
Table 6. LDA classification results of the storage data set based on the results of ET and NIRS.

\begin{tabular}{|c|c|c|c|c|c|c|c|c|c|c|c|c|c|}
\hline \multirow[b]{2}{*}{ Accuracy } & \multirow[b]{2}{*}{ Storage Type } & \multicolumn{5}{|c|}{ Electronic Tongue } & \multicolumn{7}{|c|}{ NIR } \\
\hline & & $\begin{array}{l}\text { Grafted } \\
\text { Fresh }\end{array}$ & $\begin{array}{l}\text { Grafted } \\
2^{\circ} \mathrm{C}\end{array}$ & $\begin{array}{l}\text { Self Root } \\
\text { Fresh }\end{array}$ & $\begin{array}{c}\text { Self Root } \\
2^{\circ} \mathrm{C}\end{array}$ & $\begin{array}{c}\text { Self Root } \\
17^{\circ} \mathrm{C}\end{array}$ & Accuracy & Storage type & $\begin{array}{l}\text { Grafted } \\
\text { Fresh }\end{array}$ & $\begin{array}{l}\text { Grafted } \\
2{ }^{\circ} \mathrm{C}\end{array}$ & $\begin{array}{l}\text { Self Root } \\
\text { fresh }\end{array}$ & $\begin{array}{c}\text { Self Root } \\
2^{\circ} \mathrm{C}\end{array}$ & $\begin{array}{c}\text { Self Root } \\
17^{\circ} \mathrm{C}\end{array}$ \\
\hline \multirow{5}{*}{$\begin{array}{l}\text { Training } \\
92.10 \%\end{array}$} & Grafted fresh & 86.7 & 20 & 0 & 0 & 2.91 & \multirow{5}{*}{$\begin{array}{c}\text { Training } \\
100 \%\end{array}$} & Grafted fresh & 100 & 0 & 0 & 0 & 0 \\
\hline & Grafted $2{ }^{\circ} \mathrm{C}$ & 13.3 & 76.7 & 0 & 0 & 0 & & Grafted $2{ }^{\circ} \mathrm{C}$ & 0 & 100 & 0 & 0 & 0 \\
\hline & Self root fresh & 0 & 0 & 100 & 0 & 0 & & Self root fresh & 0 & 0 & 100 & 0 & 0 \\
\hline & Self root $2{ }^{\circ} \mathrm{C}$ & 0 & 0 & 0 & 100 & 0 & & Self root $2{ }^{\circ} \mathrm{C}$ & 0 & 0 & 0 & 100 & 0 \\
\hline & Self root $17^{\circ} \mathrm{C}$ & 0 & 3.3 & 0 & 0 & 97.09 & & Self root $17^{\circ} \mathrm{C}$ & 0 & 0 & 0 & 0 & 100 \\
\hline \multirow{5}{*}{$\begin{array}{c}\text { Validation } \\
87.03 \%\end{array}$} & Grafted fresh & 80 & 13.4 & 0 & 0 & 5.83 & \multirow{5}{*}{$\begin{array}{c}\text { Validation } \\
84.46 \%\end{array}$} & Grafted fresh & 77.83 & 5.51 & 0 & 0 & 0 \\
\hline & Grafted $2{ }^{\circ} \mathrm{C}$ & 20 & 80 & 6.6 & 0 & 5.83 & & Grafted $2{ }^{\circ} \mathrm{C}$ & 11.17 & 88.98 & 5.5 & 0 & 0 \\
\hline & Self root fresh & 0 & 0 & 93.4 & 6.6 & 0 & & Self root fresh & 5.5 & 5.51 & 77.83 & 11.17 & 0 \\
\hline & Self root $2{ }^{\circ} \mathrm{C}$ & 0 & 0 & 0 & 93.4 & 0 & & Self root $2^{\circ} \mathrm{C}$ & 0 & 0 & 5.5 & 88.83 & 11.17 \\
\hline & Self root $17^{\circ} \mathrm{C}$ & 0 & 6.6 & 0 & 0 & 88.34 & & Self root $17^{\circ} \mathrm{C}$ & 5.5 & 0 & 11.17 & 0 & 88.83 \\
\hline
\end{tabular}




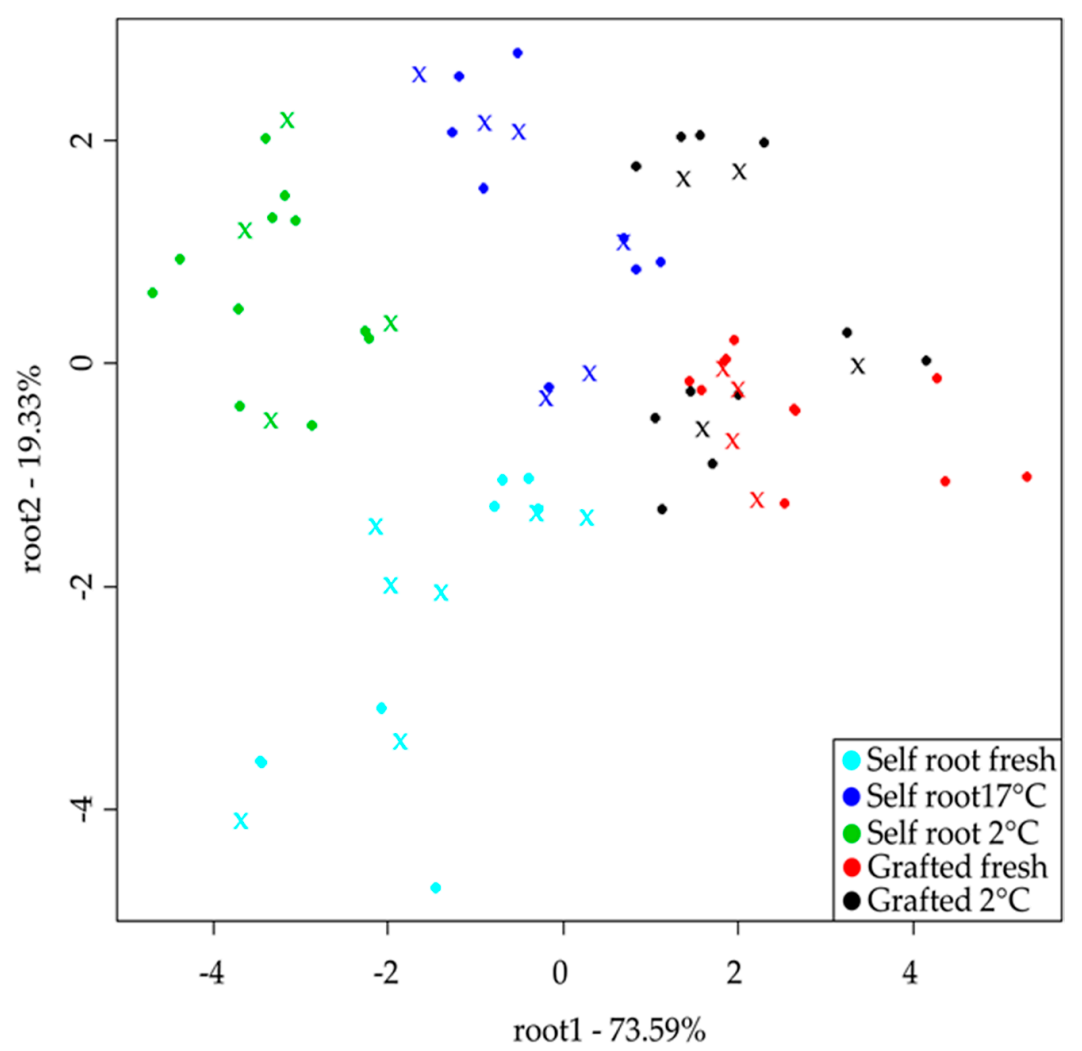

Figure 4. LDA classification results of the electronic tongue for differentiation of the five storage groups after drift correction and outlier detection $(n=77)$ otraining $\times$ validation.

3.4. Results of Partial Least Square Regression Models for Sensory and Chemical Parameters Predicted from PLSR Results of the Electronic Tongue and NIRS

PLSR results predicted of the results of the electronic tongue and NIRS of the variety data set for chemical parameters and sensory parameters can be seen in Table 7. The best PLSR model for NIRS analysis showed an $\mathrm{R}^{2} \mathrm{CV}$ of 0.96 for the Brix ${ }^{\circ}$ content and a low error of $0.29 \mathrm{~g} / \mathrm{mg}$. With the exception of $\beta$-carotene and total carotene, all the other standard analytical parameters had a low RMSECV between $0.15 \mathrm{~g} / \mathrm{mg}-3.2 \mathrm{~g} / \mathrm{mg}$. In the case of the variety data set the best results were obtained for electronic tongue prediction of total carotene, $\beta$-carotene, cis- $\beta$-carotene, violaxanthin and vitamin $C$ content, while in sensory parameters the taste persistency sweet aroma and juiciness of melons could be predicted with the highest correlation $\left(R^{2} C\right.$ and $\left.R^{2} C V>0.8000\right)$ between the measured and predicted values. In the case of phytoene and phytofluene no good model was found.

In the case of the e-tongue analysis of storage data set (Table 8), the highest correlation between measured and predicted value was obtained in the case of $\zeta$-carotene, Brix ${ }^{\circ}$, for sensory in the case of sweet taste and aftertaste. Prediction by the NIRS data set provided the best result for Brix ${ }^{\circ}$ with the correlation of $R^{2}=0.9981$ for recognition and $R^{2} C V=0.9585$ for validation. In the case of results of the sensory test, the aftertaste, melon aroma, sweet taste and taste persistency could be estimated with the highest correlation between measured and predicted values. 
Table 7. Results of PLSR for the standard analytical parameters (values are in $\mu \mathrm{g} / \mathrm{mL}$ ) and sensory parameters predicted by ET and NIRS for variety data set.

\begin{tabular}{|c|c|c|c|c|c|c|c|c|c|c|c|c|c|}
\hline & \multirow[b]{2}{*}{ Parameters } & \multicolumn{6}{|c|}{ Electronic Tongue } & \multicolumn{6}{|c|}{ NIRS } \\
\hline & & Latent variables & Data Points & $\mathbf{R}^{2} \mathrm{C}$ & RMSEC & $\mathrm{R}^{2} \mathrm{CV}$ & RMSECV & Latent Variables & Data Points & $\mathbf{R}^{2} \mathbf{C}$ & RMSEC & $\mathrm{R}^{2} \mathrm{CV}$ & RMSECV \\
\hline \multirow{10}{*}{ 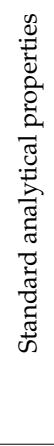 } & Brix $^{\circ}$ & 5 & 56 & 0.4238 & 0.9949 & 0.2633 & 1.1241 & 20 & 45 & 0.9981 & 0.0625 & $0.9585^{*}$ & 0.2914 \\
\hline & $\beta$-carotene & 6 & 56 & 0.89 & 7.3223 & 0.8516 & 8.4964 & 17 & 45 & 0.9462 & 5.9835 & 0.4645 & 18.87 \\
\hline & Cis- $\beta$-carotene & 6 & 56 & 0.8987 & 0.0915 & 0.8672 & 0.1046 & 10 & 45 & 0.8279 & 0.1244 & 0.3683 & 0.2384 \\
\hline & Chlorophyll A & 2 & 24 & 0.7432 & 0.1543 & 0.6330 & 0.1840 & 3 & 18 & 0.3738 & 0.2204 & 0.0831 & 0.2666 \\
\hline & Chlorophyll B & 2 & 24 & 0.6978 & 0.1829 & 0.5639 & 0.2194 & 4 & 18 & 0.6263 & 0.1826 & 0.1345 & 0.278 \\
\hline & Luthein & 4 & 56 & 0.6651 & 0.1503 & 0.5821 & 0.1677 & 10 & 45 & 0.7611 & 0.12 & 0.2719 & 0.2095 \\
\hline & Total carotene & 6 & 56 & 0.8914 & 7.5094 & 0.8528 & 8.7341 & 17 & 45 & 0.9468 & 6.1248 & 0.461 & 19.487 \\
\hline & Violaxanthin & 5 & 56 & 0.8108 & 0.1068 & 0.7632 & 0.1194 & 12 & 45 & 0.8868 & 0.0771 & 0.5461 & 0.1545 \\
\hline & Vitamin C & 6 & 55 & 0.8967 & 5.2308 & 0.8653 & 5.9682 & 20 & 27 & 0.9993 & 0.1154 & 0.4456 & 3.284 \\
\hline & $\zeta$-carotene & 5 & 56 & 0.7935 & 0.5842 & 0.7402 & 0.6547 & 11 & 45 & 0.8503 & 0.5123 & 0.4768 & 0.9578 \\
\hline \multirow{10}{*}{ 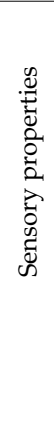 } & Aftertaste & 1 & 100 & 0.0354 & 5.4113 & 0.0112 & 5.4783 & 5 & 65 & 0.29 & 4.7568 & 0.0564 & 5.4839 \\
\hline & Flesh color & 5 & 100 & 0.6976 & 13.939 & 0.6494 & 15.0047 & 3 & 64 & 0.2617 & 21.941 & 0.1917 & 22.959 \\
\hline & Fermented taste & 4 & 100 & 0.3362 & 13.4063 & 0.2486 & 14.2658 & 5 & 63 & 0.4427 & 12.277 & 0.2648 & 14.101 \\
\hline & Fermented aroma & 5 & 100 & 0.2732 & 10.3195 & 0.1739 & 10.9991 & 5 & 67 & 0.2828 & 10.208 & 0.0486 & 11.757 \\
\hline & Melon aroma & 4 & 100 & 0.7324 & 6.5185 & 0.7007 & 6.8916 & 5 & 63 & 0.5666 & 8.2204 & 0.349 & 10.074 \\
\hline & Sweet aroma & 4 & 100 & 0.8186 & 4.9681 & 0.7962 & 5.2654 & 5 & 61 & 0.6613 & 6.7504 & 0.572 & 7.5884 \\
\hline & Sweet taste & 5 & 100 & 0.3231 & 6.9736 & 0.2277 & 7.4468 & 5 & 67 & 0.4238 & 6.6587 & 0.2651 & 7.5201 \\
\hline & Taste persistency & 5 & 100 & 0.803 & 2.4503 & 0.7761 & 2.612 & 5 & 59 & 0.7694 & 2.634 & 0.6815 & 3.0959 \\
\hline & Texture & 5 & 100 & 0.2017 & 6.5978 & 0.0995 & 7.0073 & 4 & 60 & 0.0631 & 7.0443 & 0.0043 & 7.2623 \\
\hline & Juiciness & 5 & 100 & 0.9206 & 8.4033 & 0.9087 & 9.0062 & 4 & 60 & 0.6787 & 16.415 & 0.6164 & 17.936 \\
\hline
\end{tabular}

$\mathrm{R}^{2} \mathrm{C}$ : Coefficient of determination; RMSEC: Root meant error of calibration; $\mathrm{R}^{2} \mathrm{CV}$ : Coefficient of determination of cross validation; RMSECV; Root mean square error cross validation. 
Table 8. Results of PLSR for the standard analytical and sensory parameters predicted by ET and NIRS for the storage data set.

\begin{tabular}{|c|c|c|c|c|c|c|c|c|c|c|c|c|c|}
\hline & \multirow[b]{2}{*}{ Parameters } & \multicolumn{6}{|c|}{ Electronic Tongue } & \multicolumn{6}{|c|}{ NIRS } \\
\hline & & Latent Variables & Data Points & $\mathbf{R}^{2} \mathbf{C}$ & RMSEC & $\mathrm{R}^{2} \mathrm{CV}$ & RMSECV & Latent Variables & Data Points & $\mathbf{R}^{2} \mathbf{C}$ & RMSEC & $\mathrm{R}^{2} \mathrm{CV}$ & RMSECV \\
\hline \multirow{11}{*}{ 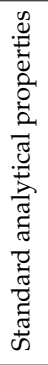 } & Brix ${ }^{\circ}$ & 1 & 50 & 0.816 & 0.6806 & 0.8002 & 0.7088 & 12 & 26 & 0.9992 & 0.0459 & 0.8144 & 0.6827 \\
\hline & $\beta$-carotene & 4 & 44 & 0.4975 & 22.1737 & 0.3256 & 25.6006 & 15 & 31 & 0.9424 & 8.5495 & -0.012 & 35.83 \\
\hline & Cis- $\beta$-carotene & 4 & 44 & 0.6083 & 2.4284 & 0.4579 & 2.8537 & 15 & 32 & 0.9009 & 1.3535 & -0.7949 & 5.7594 \\
\hline & Lutein & 2 & 44 & 0.4167 & 0.1119 & 0.2942 & 0.123 & 6 & 34 & 0.6707 & 0.0789 & 0.3939 & 0.1071 \\
\hline & Mutatoxanthin & 4 & 44 & 0.5812 & 0.0611 & 0.3668 & 0.075 & 15 & 35 & 0.9488 & 0.0197 & -0.7132 & 0.1138 \\
\hline & Phytoene & 3 & 44 & 0.5141 & 0.509 & 0.3423 & 0.5912 & 15 & 32 & 0.9233 & 0.2114 & -1.0245 & 1.0861 \\
\hline & Phytofluene & 3 & 44 & 0.4029 & 0.7909 & 0.2069 & 0.9103 & 15 & 31 & 0.8681 & 0.3804 & -2.5857 & 1.9833 \\
\hline & Total carotene & 4 & 44 & 0.5446 & 22.9254 & 0.3812 & 26.6193 & 15 & 31 & 0.9717 & 6.3529 & 0.3484 & 30.486 \\
\hline & Violaxanthin & 2 & 44 & 0.3022 & 0.092 & 0.1165 & 0.1034 & 15 & 30 & 0.9653 & 0.0209 & 0.0226 & 0.111 \\
\hline & Vitamin C & 2 & 26 & 0.6897 & 34.9167 & 0.6054 & 39.3004 & 15 & 25 & 0.9684 & 9.3388 & -1.5506 & 83.949 \\
\hline & $\zeta$-carotene & 4 & 44 & 0.7914 & 1.0283 & 0.6613 & 1.3087 & 15 & 32 & 0.8962 & 0.675 & -5.037 & 5.1466 \\
\hline \multirow{10}{*}{ 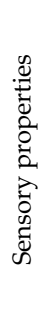 } & Aftertaste & 1 & 60 & 0.7987 & 13.8018 & 0.7849 & 14.2621 & 10 & 57 & 0.9465 & 7.0339 & 0.8525 & 11.68 \\
\hline & Flesh color & 2 & 60 & 0.4079 & 9.2906 & 0.3198 & 9.9535 & 10 & 56 & 0.8184 & 5.2774 & -0.0275 & 12.552 \\
\hline & Fermented taste & 1 & 60 & 0.7665 & 2.2761 & 0.7496 & 2.3565 & 10 & 61 & 0.906 & 1.4383 & 0.7737 & 2.2312 \\
\hline & Fermented aroma & 1 & 60 & 0.4747 & 3.9534 & 0.4355 & 4.0971 & 10 & 56 & 0.8635 & 1.9815 & 0.6549 & 3.1509 \\
\hline & Melon aroma & 2 & 60 & 0.7297 & 5.0735 & 0.6945 & 5.3917 & 10 & 54 & 0.9605 & 1.9787 & 0.8641 & 3.672 \\
\hline & Sweet aroma & 3 & 60 & 0.7556 & 6.0293 & 0.7136 & 6.5138 & 10 & 61 & 0.8868 & 4.0793 & 0.7286 & 6.3175 \\
\hline & Sweet taste & 1 & 60 & 0.8038 & 9.1659 & 0.7901 & 9.4765 & 10 & 59 & 0.9458 & 4.7997 & 0.8503 & 7.975 \\
\hline & Taste persistency & 2 & 60 & 0.772 & 9.4545 & 0.7433 & 10.028 & 10 & 54 & 0.9438 & 4.6644 & 0.8334 & 8.0325 \\
\hline & Texture & 1 & 60 & 0.7651 & 10.1466 & 0.748 & 10.5051 & 10 & 61 & 0.9056 & 6.4052 & 0.7737 & 9.9156 \\
\hline & Juiciness & 1 & 60 & 0.7738 & 15.3924 & 0.7574 & 15.9337 & 10 & 61 & 0.9036 & 10.009 & 0.745 & 16.279 \\
\hline
\end{tabular}




\section{Discussion}

\subsection{Color Classification}

Electronic tongue results showed complete separation of Cantaloupe type (orange-fleshed) and Galia type melons (green) from each other (Figure 3). This phenomenon was also observed in the results of standard analytical methods, where significant differences were found in all parameters, showing that these two types are different in chemical composition (Table 1). Discrimination between these two-colored melon types was also confirmed with the NIRS, where there was no misclassification of color. Discriminating melon colors is an important parameter that is often associated with ripeness and plays a key role in consumer perception of food items before purchase. Galia melon is a hybrid originating from a Cantaloupe-Honeydew cross; ripeness is measured not by softness at the stem, but rather by color and fragrance [32]. According to Sánchez et al. (2014), Cantaloupe type melons may be harvested, when the external color beneath the netting begins to change from green to yellow-green because the skin color gradually changes light yellow, but the orange-fleshed pulp requires non-destructive methods in order to avoid damage to the fruit at full ripeness [25]. With a non-permeable advantage, NIRS can be combined with existing methods for quick profiling of melons according to their color. Generally, the NIRS and E-tongue showed similar results for the discrimination of the two main types, results obtained in the detailed evaluation (Tables 3-8). Were differences in the results of the two instruments, which may be due to their unique advantages and disadvantages showed in Table 9.

Table 9. Properties of the electronic tongue and NIRS as analytical methods.

\begin{tabular}{ccc}
\hline Attribute/Function & E-Tongue & NIRS \\
Quick & Yes & Yes \\
Non-destructive & No & Yes \\
No waste (use of reagents) & Yes & Yes \\
Less labor & Yes & Yes \\
Relatively low cost and safe application & Yes & Yes \\
Sophisticated & No & Yes \\
Drift & Yes & No \\
High selectivity and sensitivity & Yes & Yes \\
Small sample size required & No & Yes \\
Quantification and classification & Yes & Yes \\
Temperature sensitive & Yes & Yes \\
Advanced (complex) data analysis & Yes & Yes \\
Small and portable instrument size & No* & Yes \\
High precision & Yes & Yes \\
Calibration is dependent on food constituent & Yes & Yes \\
Easy to install (maintenance) & Yes & Yes \\
Flexibility (simultaneous analysis) & Yes & Yes \\
Dependence on reference information & Yes & Yes
\end{tabular}

* commercial E-tongue instruments are usually bench-top types.

\subsection{Melon Classification Based on Varieties}

Sensory results of the Cantaloupe type melons showed that Celestial variety had the best result for most of the attributes investigated. This pattern was confirmed in the NIRS results in Table 5 where Celestial had the highest validation accuracy of 93.4\%. Centro variety significantly differed from one of the other types in juiciness, texture, fermented aroma and fermented taste (Figure 2a), and this pattern was also distinguished in the LDA model built for the results of the electronic tongue from the Donatello and Celestial groups (Figure 3).

Sensory results of Galia type melons shows significant difference only for fermented taste and aroma (Figure 2b); however, these type could be differentiated at high accuracy by the electronic 
tongue, showing that the electronic tongue is more sensible not only for differentiating different types of melons, but also different varieties in the same type. Classification accuracies from the NIRS were also in line with this observation and agreed with studies by Seregély et al. (2004) when they discriminated different varieties of hybrid melon with NIRS [33].

\subsection{Melon Classification Based on Storage and Growth Conditions (Grafted or Self-Rooted)}

Sensory results of storage data sets showed significant differences in eight parameters from the ten between grafted and self-root melons (Figure 2c,d), and these two types also could be distinguished from each other based on the results of the electronic tongue and NIRS (Table 6). The results obtained for classification of grafted and self-rooted melons with the electronic tongue are better than obtained for previous studies for watermelons, where technological and environmental conditions had a higher role in the differentiation of samples [21]. It is also true for the melons stored at $2{ }^{\circ} \mathrm{C}$, showing that the electronic tongue is in accordance with the results of the sensory test (Table 6). Cantaloupe melons are recommended to be stored at temperatures of $0-5{ }^{\circ} \mathrm{C}$ for maximum preservation of their qualities [34]. The high classification accuracy $(88.34 \%$ with an electronic tongue and $88.83 \%$ with NIRS) of self-rooted melons stored at a higher temperature $\left(17^{\circ} \mathrm{C}\right)$ compared to those stored at lower temperatures explains the influence of temperature on melon quality.

\subsection{PLSR Prediction of Melon Qualities}

In PLSR, an $R^{2}$ close to 1 is a necessary condition for a good model [35], but this may not be the only requirement. The errors in calibration: root mean square error in cross validations (RMSECV) explains the fit of the observations to the model in both calibration and validation steps. It is a measure of the average difference between the values determined by the reference methods and those predicted by the model [36]. PLSR for electronic tongue provided the best results in the case of carotenes for the variety data set (Table 7), this could be the results of the significant differences between the varieties found for these parameters (Table 1). The same trend is true for the storage data set where Brix ${ }^{\circ}$ provided the best results in PLSR (Table 8 ) and ANOVA test also found four different subsets for the five storage types (Table 2). With the exception of Brix ${ }^{\circ}$, the electronic tongue could generally, predict storage and standard analytical parameters better than the NIRS. Ref. [24] and Ref. [37] also reported much better results in their study for brix prediction in melon with NIRS. According to [33], the main difficulty of NIRS studies may be because NIRS measures the physical (optical) properties that are determined by chemical compounds and molecular structures, this may have accounted for the poor NIRS prediction results.

\section{Conclusions}

In the present study, we evaluated the influence of storage condition and grafting of melon cultivars testing and based on the instrumental and organoleptic examination, and according to the main question posed, we can conclude the follows:

ANOVA results showed significant differences in each standard analytical parameter between Cantaloupe type (orange-fleshed) and Galia type melons (green). There were also significant differences in the five melon varieties, according to their flesh color. Significant differences were also observed in different storage conditions.

Correlative analytical techniques (electronic tongue and Metri NIRS) confirmed the ANOVA results with a complete separation of both Cantaloupe type (orange-fleshed) and Galia type melons (green), thus, ascertaining their chemical variations. Celestial variety had the best result for most of the attributes investigated, in agreement with the NIRS results.

Sensory results of Galia type melons shows significant difference only for fermented taste and aroma; however, these typed could be differentiated at high accuracy by the electronic tongue. Sensory results of storage data sets showed significant differences in eight parameters from the ten between 
grafted and self-root melons, and these two types also could be distinguished from each other based on the results of the electronic tongue and NIRS.

Partial least squares regression models with the electronic tongue provided the best accuracy in the case of carotenes for the variety data set and the best for brix in the storage data set.

Generally, the electronic tongue could predict storage and standard analytical parameters better than the NIRS, but NIRS showed higher classification accuracies. Combining both electronic tongue and near-infrared spectroscopy provides a rapid, non-destructible means of monitoring melon varieties and the effect of storage on the quality of Cantaloupe type (orange-fleshed) and Galia type melons (green-fleshed).

Author Contributions: All authors contributed to this research. The design of the experiment was done by D.N., G.B. and N.K. Z.K. (Zoltán Kovács), Z.B. and J.-L.Z.Z. did the recording and the processing of the sensory and NIRS data, as well as the result of the evaluation. H.G.D. contributed to the implementation of HPLC measurements, Z.K. (Zoltán Kókai) by the sensory evaluation tests. The manuscript was written by D.N., Z.B., J.-L.Z.Z. and Z.K. (Zoltán Kovács). V.S. assisted in writing the paper. N.K. and Z.K. (Zoltán Kovács) contributed to designing the research and revised the manuscript. The work presented in the paper was conceived within research projects led by N.K. and Z.K. (Zoltán Kovács).

Funding: Supported by the by the ÚNKP-19-3 (D.N., Z.B.) and ÚNKP-19-4 (Z.K. (Zoltán Kovács)) New National Excellence Program of the Ministry for Innovation and Technology; Supported by the Bolyai János Scholarship of the Hungarian Academy of Sciences (Z.K. (Zoltán Kovács)); The project was supported by the Doctoral School of Food Science and Doctoral School of Horticultural Science, Szent István University (Z.B., J.-L.Z.Z., D.N.); The project is supported by the European Union and co-financed by the European Social Fund (grant agreement no. EFOP-3.6.3-VEKOP-16-2017-00005); This research was supported by the Higher Education Institutional Excellence Program (20430-3/2018/FEKUTSTRAT) awarded by the Ministry of Human Capacities within the framework of plant breeding and plant protection research at Szent István University; This publication is created in number EFOP-3.6.1-16-2016-00016. The SZIE Campus of Szarvas specialized in research and training profiles with intelligent specialization in the themes of water management, hydroculture, precision mechanical engineering, alternative crop production"; This research was supported by the Higher Education Institutional Excellence Program (1783-3/2018/FEKUTSTRAT) awarded by the Ministry of Human Capacities within the framework of water-related research at Szent István University.

Conflicts of Interest: The authors declare no conflict of interest.

\section{References}

1. FAOSTAT. Available online: http://www.fao.org (accessed on 16 November 2019).

2. Louws, F.J; Rivard, C.L.; Kubota, C. Grafting fruiting vegetables to manage soilborne pathogens, foliar pathogens, arthropods and weeds. Sci. Hortic. (Amst.) 2010, 127, 127-146. [CrossRef]

3. Rouphael, Y.; Rea, E.; Cardarelli, M.; Bitterlich, M.; Schwarz, D.; Colla, G. Can Adverse Effects of Acidity and Aluminum Toxicity Be Alleviated by Appropriate Rootstock Selection in Cucumber? Front. Plant Sci. 2016, 7, 1283. [CrossRef] [PubMed]

4. Oda, J.L.M.; Lee, M. Grafting of herbaceous vegetable and ornamental crops. Hortic. Rev. 2003, 28, 61-124.

5. Escribano, S.; Sánchez, F.J.; Lázaro, A. Establishment of a sensory characterization protocol for melon (Cucumis melo L.) and its correlation with physical-chemical attributes: Indications for future genetic improvements. Eur. Food Res. Technol. 2010, 231, 611-621. [CrossRef]

6. Imatsu, T. On the symbiotic affinity caused by the grafting among Cucurbitaceae species. J. Jpn. Soc. Hortic. Sci. 1949, 18, 36-42. [CrossRef]

7. Miguel, A.; De la Torre, F.; Baixauli, C.; Maroto, J.V.; Jordá, M.C.; López, M.M.; García-Jímenez, J. Injerto de Hortalizas; Serie Divulgaci'on T'ecnica. Conseller'1a de Agricultura; Generalitat Valenciana: Valencia, Spain, 1997; pp. 50-52. ISBN 9788448216016.

8. Chuanqiang, X.; Tianlai, L.; Hongyan, Q. Effects of Grafting on Development, Carbohydrate Content and Sucrose-metabolizing Enzymes Activities of Muskmelon Fruit. Acta Hortic. Sin. 2006, 33, 773.

9. Burger, Y.; Sa'ar, U.; Paris, H.S.; Lewinsohn, E.; Katzir, N.; Tadmor, Y.; Schaffer, A.A. Genetic variability for valuable fruit quality traits in Cucumis melo. Isr. J. Plant Sci. 2006, 54, 233-242. [CrossRef]

10. Bíró, G.; Lindner, K. Tápanyagtáblázat; Medicina Könyvkiadó: Budapest, Hungary, 1988. 
11. Condurso, C.; Verzera, A.; Dima, G.; Tripodi, G.; Crinò, P.; Paratore, A.; Romano, D. Effects of different rootstocks on aroma volatile compounds and carotenoid content of melon fruits. Sci. Hortic. (Amst.) 2012, 148, 9-16. [CrossRef]

12. Zhou, X.; Wu, Y.; Chen, S.; Chen, Y.; Zhang, W.; Sun, X.; Zhao, Y. Using Cucurbita rootstocks to reduce fusarium wilt incidence and increase fruit yield and carotenoid content in oriental melons. HortScience 2014, 49, 1365-1369. [CrossRef]

13. Verzera, A.; Dima, G.; Tripodi, G.; Condurso, C.; Crinò, P.; Romano, D.; Mazzaglia, A.; Lanza, C.M.; Restuccia, C.; Paratore, A. Aroma and sensory quality of honeydew melon fruits (Cucumis melo L. subsp. melo var. inodorus H. Jacq.) in relation to different rootstocks. Sci. Hortic. (Amst.) 2014, 169, 118-124. [CrossRef]

14. Horváth, V. A Sárgadinnye Különböző Tárolástechnológiai Módszereinek Feltátása az Eltarthatósági idő Növelésére; Budapesti Corvinus Egyetem: Budapest, Hungary, 2016.

15. Özdemir, A.E.; Çandır, E.; Yetişir, H.; Aras, V.; Arslan, Ö.; Baltaer, Ö.; Üstün, D.; Ünlü, M. Effects of rootstocks on storage and shelf life of grafted watermelons. J. Appl. Bot. Food Qual. 2016, 89, 191-201. [CrossRef]

16. Vallone, S.; Sivertsen, H.; Anthon, G.E.; Barrett, D.M.; Mitcham, E.J.; Ebeler, S.E.; Zakharov, F. An integrated approach for flavour quality evaluation in muskmelon (Cucumis melo L. reticulatus group) during ripening. Food Chem. 2013, 139, 171-183. [CrossRef] [PubMed]

17. Park, E.; Luo, Y.; Marine, S.C.; Everts, K.L.; Micallef, S.A.; Bolten, S.; Stommel, J. Postharvest Biology and Technology Consumer preference and physicochemical evaluation of organically grown melons. Postharvest Biol. Technol. 2018, 141, 77-85. [CrossRef]

18. Kantor, D.B.; Hitka, G.; Fekete, A.; Balla, C. Electronic tongue for sensing taste changes with apricots during storage. Sens. Actuators B Chem. 2008, 131, 43-47. [CrossRef]

19. Escuder-Gilabert, L.; Peris, M. Review: Highlights in recent applications of electronic tongues in food analysis. Anal. Chim. Acta 2010, 665, 15-25. [CrossRef]

20. Tian, X.; Wang, J.; Zhang, X. Discrimination of preserved licorice apricot using electronic tongue. Math. Comput. Model. 2013, 58, 743-751. [CrossRef]

21. Fekete, D.; Balázs, G.; Bőhm, V.; Várvölgyi, E.; Kappel, N. Sensory evaluation and electronic tongue for sensing grafted and non-grafted watermelon taste attributes. Acta Aliment. 2018, 47, 487-494. [CrossRef]

22. Guo, T.; Yin, T.; Ma, Z.; Wang, Z.; Sun, X.; Yuan, W. Characterization of different processes lemon slice using electronic tongue. IFAC-PapersOnLine 2018, 51, 683-688. [CrossRef]

23. Nicolaï, B.M.; Beullens, K.; Bobelyn, E.; Peirs, A.; Saeys, W.; Theron, K.I.; Lammertyn, J. Nondestructive measurement of fruit and vegetable quality by means of NIR spectroscopy: A review. Postharvest Biol. Technol. 2007, 46, 99-118. [CrossRef]

24. Hu, R.; Zhang, L.; Yu, Z.; Zhai, Z.; Zhang, R. Optimization of soluble solids content prediction models in 'Hami' melons by means of Vis-NIR spectroscopy and chemometric tools. Infrared Phys. Technol. 2019, 102, 102999. [CrossRef]

25. Sánchez, M.T.; Torres, I.; De la Haba, M.J.; Pérez-Marín, D. First steps to predicting pulp colour in whole melons using near-infrared reflectance spectroscopy. Biosyst. Eng. 2014, 123, 12-18. [CrossRef]

26. Sun, M.; Zhang, D.; Liu, L.; Wang, Z. How to predict the sugariness and hardness of melons: A near-infrared hyperspectral imaging method. Food Chem. 2017, 218, 413-421. [CrossRef] [PubMed]

27. Daood, H.G.; Palotas, G.; Palotas, G.; Somogyi, G.; Pek, Z.; Helyes, L. Carotenoid and antioxidant content of ground paprika from indoor-cultivated traditional varieties and new hybrids of spice red peppers. Food Res. Int. 2014, 65, 231-237. [CrossRef]

28. ISO. ISO International Standard ISO 13299: Sensory analysis—Methodology—General Guidance for Establishing a Sensory Profile; ISO: Geneva, Switzerland, 2003.

29. ISO. ISO International Standard ISO 8589: Sensory Analysis: General Guidance for the Design of Test Rooms; ISO: Geneva, Switzerland, 2007.

30. Alpha MOS. $\alpha$ Astree Electronic Tongue User Manual; Alpha MOS: Toulouse, France, 2003.

31. Kovacs, Z.; Pollner, B. Aquaphotomics-Software R-Package „aquap2“. In Proceedings of the Understanding Water in Biology 2nd International Symposium, Kobe, Japan, 26-29 November 2016; Volume 1, pp. 18-20.

32. Escribano, S.; Lázaro, A. Sensorial characteristics of Spanish traditional melon genotypes: Has the flavor of melon changed in the last century? Eur. Food Res. Technol. 2012, 234, 581-592. [CrossRef] 
33. Seregély, Z.; Deák, T.; Bisztray, G.D. Distinguishing melon genotypes using NIR spectroscopy. Chemom. Intell. Lab. Syst. 2004, 72, 195-203. [CrossRef]

34. Amaro, A.L.; Spadafora, N.D.; Pereira, M.J.; Dhorajiwala, R.; Herbert, R.J.; Müller, C.T.; Rogers, H.J.; Pintado, M. Multitrait analysis of fresh-cut cantaloupe melon enables discrimination between storage times and temperatures and identifies potential markers for quality assessments. Food Chem. 2018, 241, $222-231$. [CrossRef]

35. Aleixandre-Tudo, J.L.; Nieuwoudt, H.; Aleixandre, J.L.; du Toit, W. Chemometric compositional analysis of phenolic compounds in fermenting samples and wines using different infrared spectroscopy techniques. Talanta 2018, 176, 526-536. [CrossRef]

36. Ramírez-Morales, I.; Rivero, D.; Fernández-blanco, E.; Pazos, A. Optimization of NIR calibration models for Multipurpose processes in the food industry. Chemom. Intell. Lab. Syst. 2016, 159, 45-57. [CrossRef]

37. Sans, S.; Ferré, J.; Boqué, R.; Sabaté, J.; Casals, J.; Simó, J. Determination of chemical properties in 'calçot' (Allium cepa L.) by near infrared spectroscopy and multivariate calibration. Food Chem. 2018, 262, 178-183. [CrossRef]

(C) 2019 by the authors. Licensee MDPI, Basel, Switzerland. This article is an open access article distributed under the terms and conditions of the Creative Commons Attribution (CC BY) license (http://creativecommons.org/licenses/by/4.0/). 